\title{
Sustainable development of the Lower Vistula ${ }^{1)}$
}

\author{
Wojciech Majewski \\ Institute of Meteorology and Water Management, National Research Institute, Podleśna Street 61, 01-673 Warszawa, \\ e-mail:wojciech.majewski@imgw.pl
}

\begin{abstract}
The Vistula is the Poland's largest River. It flows from the south to the north and has its mouth in the Baltic Sea. Hydrographically the Vistula is divided into three sections: the Upper Vistula from the source to San tributary; the Middle Vistula up to the Narew tributary; and the Lower Vistula till the outlet to the sea. The Lower Vistula is $391 \mathrm{~km}$ in length. Along it there are several very important urban centers: Gdańsk with its harbor and container terminal, Elbląg with its harbor situated on the Vistula Lagoon, Tczew, Grudziądz, Włocławek, Płock and Warsaw, the capital of Poland. The Lower Vistula establishes part of the International Waterway E70 and E40 as it has important economic value and development potential. The Lower Vistula has important hydroenergy potential, is the source of water supply for people, industry and agriculture as well as being a very important ecological corridor. The whole length of the Lower Vistula, except for Włocławek Reservoir is included in the NATURA 2000 Program. The Włocławek hydraulic project lies along this section. It was commissioned in 1970 and has been the source of significant debate discussion between ecologists and water resources specialists. The Lower Vistula also benefits from scenic countryside and is popular for tourism and recreation. Along the Lower Vistula, a very important problem still exists in the form of flood hazard, mainly caused by ice phenomena and is also endangered by droughts. The paper begins with a short discussion about sustainable development. It then presents the current state of the management of the Lower Vistula and its catchment, its economic potential and plans for development. Possibilities regarding the construction of future hydraulic projects are also discussed, including the benefits for energy production, navigation, water supply, tourism and recreation.
\end{abstract}

Key words: Lower Vistula, sustainable development, navigation, water supply, hydro-energy.

Submitted 15 April 2013, received 20 November 2013, accepted 7 January 2014

\section{Sustainable development}

Sustainable development is a term that has become increasingly popular. Its definition appeared for the first time in 1972 the Stockholm Declaration. This definition was finally formulated in 1975 during second Session of UNEP. The Brundtland Report in 1987 gave the following definition: Sustainable development is economic development which takes into account environmental and social values. Subsequently numerous definitions of sustainable development have been offered. One of these definitions is as follows: Sustainable development is the development which at the present level of civilization assures the needs of the present generation without compromising the possibilities of their fulfillment to future generations.

In general we can state that sustainable development has three dimensions: economic, social and ecological. All these three aspects, in this same order, must be taken into account. It is clear that discussion and compromises must be present to achieve this aim.

This paper concerns the section of the Vistula River called the Lower Vistula, which presents large economic potential (hydro-energy, navigation, water supply and recreation). It is the site of several important cities and industrial centers, as well as ecological aspects in the form of Program NATURA 2000, which occupies the whole valley of the Lower Vistula.
This paper presents general information about the whole Vistula and its river basin, detailed description of the Lower Vistula and future prospects of its management.

\section{Introduction}

The Vistula is the largest Polish river (Piskozub 1982). Its sources are in the mountains in the south of Poland and it discharges in the north to the Baltic Sea (Bay of Gdańsk). Since the beginning of Polish history the Vistula has formed an important economic axis of the country. In the XVII century the Vistula was the most navigable river in Europe, and the connection of the area of Poland with the harbor of Gdańsk formed our window to the world. After the partition of Poland in XVIII century the Vistula's importance declined, while other European rivers developed dynamically in terms of navigation, water supply and hydro-energy.

After regaining independence in 1919 Poland began the first plans for the development of the Vistula. 20 years between the wars was too short a period for water resources development. After the Second World War, in the new geographical layout of Poland, the first comprehensive plans for the economic utilization of the Vistula were developed. A section of the Lower Vistula was especially favourably considered for navigation and hydroenergy. In 1968-71 a special comprehensive program for 
the development of the Vistula system was developed by Polish specialists with the collaboration of UN experts. Later, the special Lower Vistula Cascade program was prepared - taking into account not only hydro-energy and navigation along this section of the Vistula, but also water supply, flood protection and recreation (CASCADE 1993). The Lower Vistula comprises 50\% of the total Polish technical hydro-energy potential. As a consequence of this program, the Włocławek hydraulic project was commissioned (Majewski 2012). Preparations for the next projects downstream and upstream of Włocławek were advanced. Unfortunately, the economic crisis in Poland stopped these constructions and until today (42 years) the Włocławek project does not operate in accordance with its initial design - this has provoked various controversies.

\section{Characteristics of the Vistula river and its basin}

Vistula has large significance for the Polish economy. It is important from a social, ecological and historical point of view. The Vistula river basin measures $194000 \mathrm{~km}^{2}$ from which $87 \%\left(169000 \mathrm{~km}^{2}\right)$ is within Polish boundaries. The catchment of the Vistula occupies $54 \%$ of Polish territory and encloses important cities and industrial centers. The total length of the Vistula is $1047 \mathrm{~km}$ from its sources in the mountains to its outlet to the sea. Sometimes the distance along the Vistula is measured from Przemsza tributary, which is considered as navigable route and is $941 \mathrm{~km}$ in length. The Vistula discharges to the Baltic Sea, which has no tides. However, wind upwellings achieve a rise up to $1.5 \mathrm{~m}$ from the average sea water level. These upwellings cause backwater which ranges up to $30 \mathrm{~km}$ upstream i.e. to the water gauge Tczew located in $\mathrm{km}$ 908.6.

The Vistula is the only river in Europe of its size that is utilized to a minimum degree for hydro-energy and navigation. In some places water of the Vistula is used for cooling purposes of thermal power stations. Water from the Vistula is often abstracted for domestic, industrial and agricultural purposes.

Hydrographically the Vistula is divided into three distinctly different river sections and river basins. These are: the Upper Vistula, the Middle Vistula and the Lower Vistula. There are some other divisions based on geographical conditions. Sometimes, the most upstream section of the Vistula classified as being $105 \mathrm{~km}$ long, and is distinguished as the Small Vistula. The Vistula flows through 8 vojvodeships and its catchment falls over 11 vojvodeships.

The Small Vistula catchment closes at the Przemsza tributary and the Nowy Bierun gauge cross-section. The Upper Vistula catchment terminates with the San tributary and the Zawichost gauge. The Middle Vistula catchment ends by the Narew tributary and the Modlin gauge. Along the Lower Vistula there lies the Włocławek run-of-river reservoir, which is formed by hydraulic project of the same name, and located in $\mathrm{km}$ 675. The Kępa Polska gauge is located upstream from the reservoir, and the Torun gauge is located downstream from the reservoir. The final gauge of the Vistula is Tczew, located $32 \mathrm{~km}$ upstream from the mouth.

The division of the Vistula basin into three subcatchments (upper, middle and lower) is presented in Fig. 1.

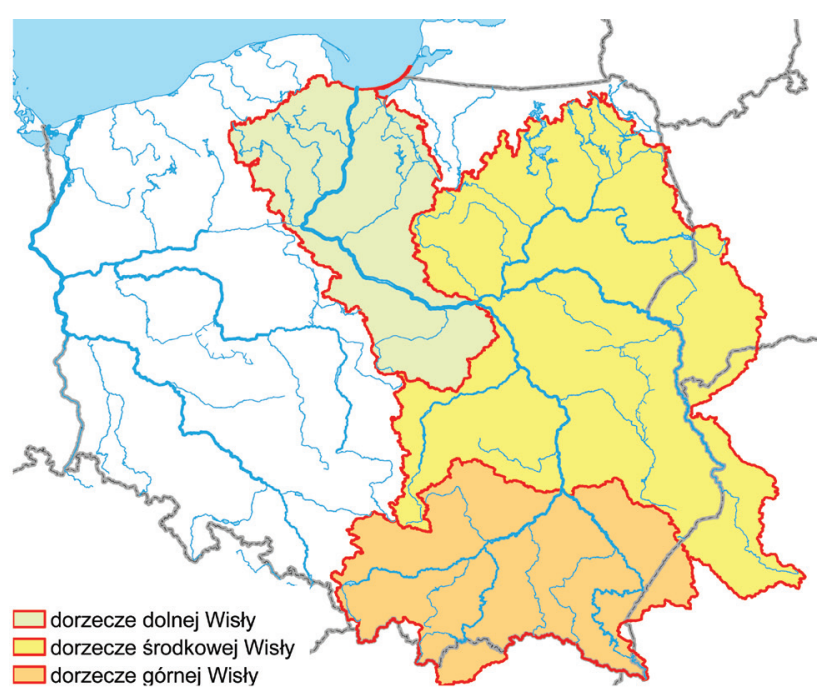

Figure 1. The division of Vistula River Basin into 3 subcatchments (source IMGW-PIB)

\subsection{Changes of discharge along the Vistula River}

It is necessary to explain that the millage of the Vistula is often counted from the tributary of Przemsza River, which ends the catchment of the Small Vistula. The section of the Vistula from the Przemsza tributary to the sea is regarded as the Vistula Waterway and has a length $941 \mathrm{~km}$. The total length of the Vistula (combined with the Small Vistula is $1047 \mathrm{~km}$ ).

The average multiyear discharge along the Vistula at 6 gauges is shown in Tab. 1.

Table 1. Multiyear average discharges of the Vistula River at consecutive gauges (source IMGW-PIB)

\begin{tabular}{|l|r|r|c|c|}
\hline \multicolumn{1}{|c|}{ Gauge } & Kilometer & $\begin{array}{c}\text { Catchment } \\
\mathrm{km}^{2}\end{array}$ & $\begin{array}{c}\text { Years of } \\
\text { observation }\end{array}$ & $\begin{array}{c}\text { Discharge } \\
\mathrm{m}^{3} / \mathrm{s}\end{array}$ \\
\hline Nowy Bieruń & 3.6 & 1780 & $1951-2011$ & 21.2 \\
\hline Zawichost & 287.6 & 50665 & $1951-2011$ & 432 \\
\hline Modlin & 551.5 & 159724 & $1969-2011$ & 880 \\
\hline Kępa Polska & 606.5 & 168358 & $1969-2011$ & 940 \\
\hline Toruń & 734.7 & 180391 & $1951-2011$ & 971 \\
\hline Tczew & 908.6 & 193807 & $1951-2011$ & 1055 \\
\hline
\end{tabular}

\subsection{The Upper Vistula}

The Upper Vistula encompasses the section from the source to the right hand San tributary. The length of this section is $399 \mathrm{~km}$ and the catchment, within Polish boundaries amounts to 45.9 thousand $\mathrm{km}^{2}$. Along this section there lies Wisła Czarne water reservoir, which was de- 
signed and developed as a source of water for domestic purposes for the settlements situated in this area. Further along this section there is Goczałkowice reservoir which was commissioned in 1956 mainly as the source of industrial water supply for the region Śląsk. Its volume is 156 million $\mathrm{m}^{3}$.

The Upper Vistula is supplied by several mountain (right-hand) tributaries - the Soła, Skawa, Raba, Dunajec, Wisłoka and San. On the river basin of the Upper Vistula lies the Śląsk agglomeration and the large cities Kraków, Rzeszów and Tarnów. The catchment of the Upper Vistula makes up about $30 \%$ of Polish water resources. Along this section there is a navigable waterway $92 \mathrm{~km}$ long from Oświęcim to Kraków, which enables the transport of 1000 tonne barges.

\subsection{The Middle Vistula}

The Middle Vistula encompasses river section from the San tributary to the Narew tributary. The length of this section is $256 \mathrm{~km}$ and its catchment (within Polish boundaries) amounts to 88.8 thousand $\mathrm{km}^{2}$. The main righthand tributary is Narew river with large confluent the Bug. The Dębe Hydraulic project on the Narew river formed the Zegrzyński reservoir, which was completed in 1963. It has a navigable connection with Warsaw by means of the Żerański Canal. It is in this area that Warsaw, the capital of Poland is situated. Warsaw has water intake for domestic purposes from the main channel of the Vistula. Two large thermal power plants have cooling water supply from the Vistula.

\section{Lover Vistula \\ 4.1. General information}

The Lower Vistula constitutes the $391 \mathrm{~km}$ long river section from the confluence of the Narew ( $\mathrm{km} \mathrm{550)}$ to its mouth in Gdańsk Bay ( $\mathrm{km} \mathrm{941).} \mathrm{The} \mathrm{catchment} \mathrm{of} \mathrm{the}$ Lower Vistula amounts to 34.3 thousand $\mathrm{km}^{2}$. It is presented in Fig. 2. The gauge cross-section Tczew is the final on the Vistula before it discharges into the Bay of Gdańsk. At this gauge the multiyear average discharge is $1055 \mathrm{~m}^{3} / \mathrm{s}$ and the maximum observed discharge after 1951 is $6480 \mathrm{~m}^{3} / \mathrm{s}$. The minimum discharge is $264 \mathrm{~m}^{3} / \mathrm{s}$. The average multiyear outflow is $33.3 \mathrm{~km}^{3}$, and minimum and maximum outflow amounts to respectively 20.5 and $50.8 \mathrm{~km}^{3}$. The Vistula supplies about $7 \%$ of fresh water to the Baltic Sea.

The discharge of the Vistula into the sea is now through an artificially formed (in 1895) direct channel (Przekop in Polish). This solution was justified mainly for the improving of outflow to the sea. The previous layout of the final Vistula section resulted in frequent and numerous winter floods, which were caused predominantly by ice jams. An ice jam in 1829 resulted in flood in the city of Gdańsk where inundation reached the second floor of buildings, causing significant economic and social losses.

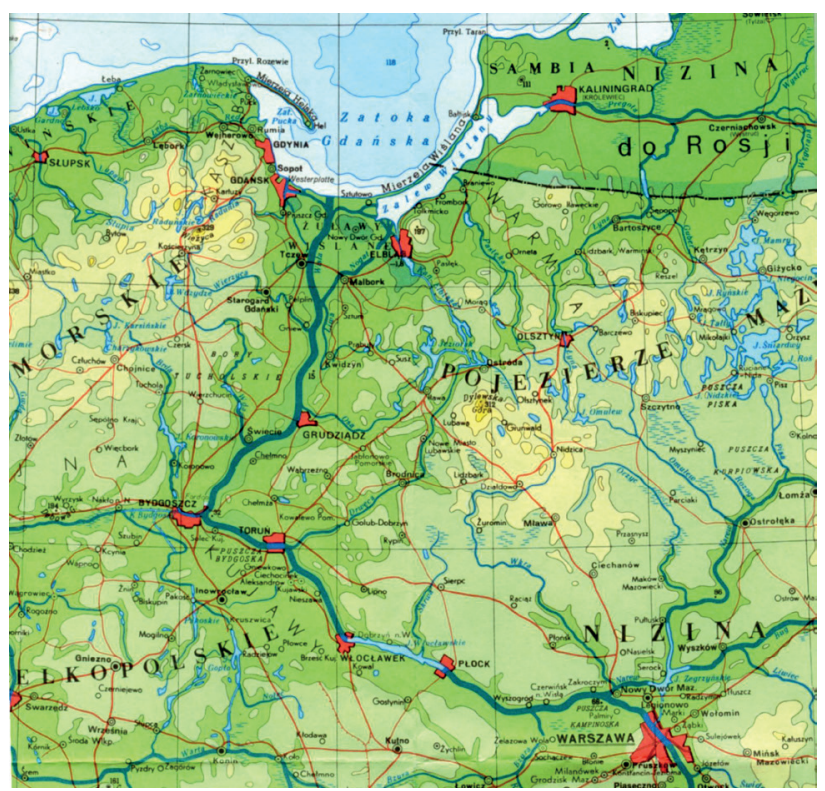

Figure 2. The catchment of the Lower Vistula

Along the Lower Vistula there are many important cities such as: Płock, Włocławek, Toruń, Bydgoszcz, Grudziądz, Tczew, Elbląg and Gdańsk. They represent not only significant industrial potential but are also important scientific and cultural centers (Fig. 2). The Lower Vistula has very important navigation potential as it connects the center of Poland (Warsaw) with the harbour of Gdańsk. Along the Lower Vistula there are sections of two international Waterways - the E70 (connecting Rotterdam with Kaliningrad and Klajpeda) and the E40, connecting the Baltic Sea with the Black Sea. At the northern part of the Lower Vistula catchment there lies the region of Żuławy, which is characterized by its very fertile soil and spans an area of about $5500 \mathrm{~km}^{2}$. Within this area there is a depression of about $450 \mathrm{~km}^{2}$. Żuławy has a very complicated system of rivers and channels, known as the Gdańsk Water Node.

The final section of the Vistula - about $200 \mathrm{~km}$ from Silno (km 718) - was trained at the end of XVIII century for navigation purposes. The Lower Vistula presents very important navigation and hydro energy potential. This section of the Vistula offers nearly $50 \%$ of the total hydro energy potential for the whole of Poland. Consequently several plans for utilization of hydroenergy have been presented. The Lower Vistula is used as the source of water supply for several industrial and municipal intakes.

\subsection{Lover Vistula Cascade}

The Lower Vistula has always been considered to hold important energy potential. During the 20-year period between the wars the first plans for the utilization of this hydro potential were considered. This period was, however, too short for the implementation of these plans. After the Second World War the idea of the comprehensive use of the Lower Vistula for navigation and hydro-energy was put forward. The first concept of the Lower Vistula 
Cascade (LVC) was presented as early as in 1957 (Cascade 1993). LVC was designed in the form of 8 hydraulic projects forming 8 run-of-river reservoirs. The distances between hydraulic projects ranged between 30 to $50 \mathrm{~km}$. It was assumed that the total installed power would be about $1300 \mathrm{MW}$ and the production of electric energy would amount in an average hydrological year to $4200 \mathrm{GWh}$. Completion of the LVC would form class IV waterway between the center of Poland (Warsaw) and the harbour of Gdańsk.

In 1970 the first Włocławek hydraulic project was commissioned. Preparation for the subsequent hydraulic projects at Ciechocinek (downstream of Włocławek) and Wyszogród (upstream from Włocławek) were advanced. Unfortunately the economic crisis stopped this important project and Włocławek operates till today individually thus creating numerous controversies.

\subsection{The Wloclawek project}

The Włocławek project is located at $\mathrm{km} 675$ of the Vistula. It consists of an earth dam, weir with 10 bays (spillways), a hydraulic power plant of with $160 \mathrm{MW}$ capacity consisting of 6 turbo-generator units, a fish pass and a navigation lock. The average multiannual discharge in the Włocławek cross-section was $890 \mathrm{~m}^{3} / \mathrm{s}$, and the discharge of $1 \%$ probability $8700 \mathrm{~m}^{3} / \mathrm{s}$. The installed discharge of the hydraulic power plant was $2190 \mathrm{~m}^{3} / \mathrm{s}$. The turbines could operate under the head from 5.2 to $12.7 \mathrm{~m}$. The design was such that in an average hydrological year energy production would amount to $750 \mathrm{GWh}$. During the current operation of Włocławek the annual energy production has ranged from 550 to $1050 \mathrm{GWh}$.

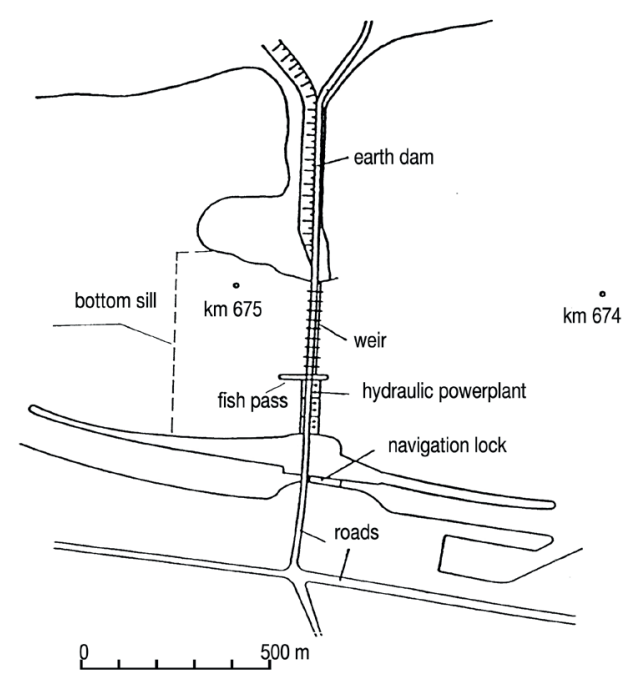

Figure 3. Layout of Włocławek Project

The Włocławek Hydraulic Project formed $55 \mathrm{~km}$ long reservoir of $400 \mathrm{mln} . \mathrm{m}^{3}$ total initial volume. The formation of the reservoir has considerably changed the existing hydrological, thermal and ice regime (Majewski 2009). The reservoir has also changed the ecological regime, though has created conditions for water withdrawal and recreational facilities. During many years of Włocławek’s operation, local erosion has appeared downstream of the project. This impeded proper operation of hydraulic power plant, weir and navigation lock. This erosion has moved in time further downstream.

The layout of the Włocławek hydraulic project is shown in Fig. 3.

\subsection{Flood hazard on the Lover Vistula}

The Lower Vistula has always presented a considerable flood hazard. This has mainly been due to the formation of ice jams, formed either of ice floes or large amounts of frazil ice. These floods have occurred either at the beginning of winter - during the formation of various forms of ice, or at the beginning of spring during ice break-up and ice-run. One of the disadvantageous characteristics of ice floods is the fact that during one winter season we have more than one ice period. In 1982 due to the extreme hydrological and meteorological conditions, there was an important and dangerous winter flood in the upper part of the Włocławek Reservoir. The main reason for this flood was the formation of extremely large amounts of frazil ice along the river section upstream from the reservoir. This flood resulted in considerable economic and social loses in the city of Płock.

Ice problems along the Lower Vistula require the active action of icebreakers. The proper operation of icebreakers requires the water of about $2 \mathrm{~m}$ in depth, and this in turn demands river training.

\subsection{Water quality}

The Vistula River was in the past, and still is very polluted. This pollution has entered the reservoir and part of it has settled, in the form of toxic sediments. Very often Włocławek Reservoir, and not the river which transported these pollutants, has been blamed for the polluted water and sediments in the reservoir. Studies concerning water quality in the reservoir have revealed that water quality leaving the reservoir is much better than water which entering the reservoir. It may be easier to remove toxic sediments from the bottom of the reservoir than to find them at the beaches near the mouth of Vistula. Arguments about polluted water and toxic sediments in the reservoir have been used by ecologists as an argument against the both existence of this reservoir and proposal of the next one. Such arguments are a complete nonsense.

\subsection{Ecological aspects}

The Vistula River as a whole is known as a large ecological corridor which is used by various species. Quite a significant part of the river is now occupied by the NATURA 2000 programme. This especially concerns the whole section of the Lower Vistula. Only the existing Włocławek 
Reservoir is excluded from this program. Along the Vistula River there are several National Parks and Landscape Parks, and a ecologists regard the Vistula River as the only wild river in Europe. On the other hand water resources specialists consider the Vistula to be the only river which does not bring any economic advantages to the country. It is difficult to understand how numerous European rivers serve ecological purposes but also bring important benefits in the form of inland navigation, recreation, water supply, and hydro-energy.

Forty years of the operation of Włocławek Reservoir revealed that biodiversity in the reservoir is much better than in the river upstream. There is abundance of new species of fish, birds and other living species. Water quality in the reservoir is at present satisfactory, and water quality downstream from reservoir has improved significantly. Włocławek Reservoir formed a new large ecological system, which has a very important influence on ground waters surrounding the reservoir.

\subsection{The next hydraulic project downstream from Wloclawek}

After the completion of the Włocławek hydraulic project preliminary preparations were carried out for the development of subsequent projects, downstream (Ciechocinek) and upstream (Wyszogród). With regard to the project in the location of Ciechocinek, technical design was completed and the preparation of grounds for the execution of the project were in progress. Unfortunately the very bad economic situation resulted in the suspension of the project.

In 2005 the Design Office Hydroproject Warsaw completed the concept of the new hydraulic project in the region Nieszawa-Ciechocinek. This concept was prepared on the order of the Regional Board for Water Management in Warsaw.

Now new hydraulic project is designed for the location of Siarzewo. This project will be equipped with a weir with 16 bays each 20 meters long. The weir has a low stable sill and segment gates with ice flaps. The normal water level in the reservoir is projected to be at the elevation of $46 \mathrm{~m}$. The hydraulic power plant will consist of 6 units with bulb turbines of total power 159.6 MW (6 x 26.6 MW), with design discharge is $1800 \mathrm{~m}^{3} / \mathrm{s}$ and the design head $4.86 \mathrm{~m}$. The project will also include a navigation lock of length $120 \mathrm{~m}$, with a lock chamber of the width $12 \mathrm{~m}$ (similar to Włocławek project). Two fish passages are also designed. A technical fish pass is located in the pier between the weir and hydraulic power plant. The ecological fish pass is on the left-hand bank and is very similar to natural streams or mountain torrents.

\section{Possible future development of the Lover Vistula}

The Lower Vistula represents a very important section of the river, and could bring numerous social and econo- mic benefits. The main problem present is the ecological constraints imposed by the NATURA 2000 Programme. This Programme covers nearly the whole valley of the Lower Vistula and expresses many objections against any new hydraulic structures. Construction of the next hydraulic project Siarzewo, downstream from Włocławek could bring numerous social and economic advantages. There are also possibilities for the fulfillment of ecological requirements, if a rational attitude from the ecological side emerges. To find a good solution, to the benefits of the present generation, requires discussion and compromises both from ecologists, economists and water management specialists.

\section{Conclusions}

The following conclusions can be presented:

- The Lower Vistula represents important hydro-energy potential. It is suitable for the development of inland navigation, water suply for agricultural, industrial and domestic purposes, as well as for various forms of recreation. It also brings numerous ecological and social benefits.

- In 1970 the Włocławek hydraulic project was commissioned as the first project of the LVC. It operates till today as a single project bringing numerous benefits, but also several drawbacks.

- Several times the construction of a new hydraulic project downstream from Włocławek has been proposed, but unfortunately its realization has always brought serious opposition from various ecological organizations.

- At present ENERGA SA is willing to develop the next hydraulic project on the Lower Vistula River at the location of Siarzewo (km 709).

- This new hydraulic project will create a new renewable source of electric energy, create an impounding reservoir about $30 \mathrm{~km}$ long, will extend a class IV inland waterway, provide new possibilities of water withdrawal for various purposes, decrease the flood hazard along the Lower Vistula downstream from the project, create new recreational facilities and, very importantly will increase the safety and operational possibilities of the Włocławek project.

\section{Bibliography}

CASCADE, 1993, Kaskada dolnej Wisły, PROEKO, Warszawa Majewski W., 2009, Przepływ w kanałach otwartych z uwzględnieniem zjawisk lodowych, Seria: Monografie IMGW, Warszawa, 112 pp

Majewski W., 2012, Następny stopień na dolnej Wiśle: szansa, zagrożenie czy konieczność, Gospodarka Wodna, 10,

Piskozub A., 1982, Wisła Monografia Rzeki, Wydawnictwo Komunikacji i Łączności, Warszawa, 447 pp 